\title{
Doğu Beyazıt'ta Asayiş ve Aşiret (1943)
}

\section{Public Order and Tribe in Doğu Beyazit (1943)}

\author{
Yücel YİĞİT* (1)
}

*Doç. Dr., Polis Akademisi, Güvenlik Bilimleri Enstitüsü, Ankara, Türkiye

ORCID: Y.Y. 0000-0003-0268-1965

\section{Sorumlu yazar/Corresponding author:}

Yücel Yiğit,

Polis Akademisi, Güvenlik Bilimleri Enstitüsü, Ankara, Türkiye

E-posta/E-mail: yigit21@hotmail.com

Başvuru/Submitted: 26.07 .2020

Revizyon Talebi/Revision Requested: 28.09.2020

Son Revizyon/Last Revision Received:

16.11.2020

Kabul/Accepted: 16.11 .2020

Atıf/Citation: Yigit, Yucel. “Doğu Beyazıt'ta Asayiş ve Aşiret (1943)." Yakın Dönem Türkiye Araştırmaları-Recent Period Turkish Studies 38 (2020): 1-24.

https://doi.org/10.26650/YTA2020-774208

\section{ÖZ}

Emniyet Genel Müdürlüğü Arşivi’nden elde edilen Ağrı isimli dosya, Sakanlı Aşireti ve Doğu Beyazıt'ın asayişi hakkında önemli bilgiler içermektedir. Araştırma, 1943 yılında Doğu Beyazıt'ta asayiş ve aşiret olaylarını inceleyen iki bölümlü bir çalışmadır. İlk bölümde; Ağrı İsyanı'nın son evresine iştirak eden, Rusya ve İran tarafından himaye edilen Sakanlı Aşireti Reisi Şeyh Abdülkadir'in siyasi tavrı ele alınmaktadır. Türkiye'de ve İran'da mukim Sakanlıların varlığı, büyük bir nüfuz sahibi olan aşiret reisinin Türkiye ile irtibatta kalmasını kolaylaştırmıştır. Çalışmanın ikinci basamağını oluşturan asayiş kısmında, Doğu Beyazıt ön plana çıkmaktadır. Zira coğrafi konumundan dolayı hırsızlık, sınır ihlali ve aşiretler arası mücadele, yoğun olarak burada yer almaktadır. Dolayısıyla rapora göre Ağrı İsyanı sonrası etnik temelli herhangi bir siyasi kalkışma söz konusu değildir. Daha çok ekonomik ihtiyaçlara yaslanan asayişe müessir suçlar işlenmiştir. Bu çalışmada Emniyet Genel Müdürlüğü Arşivi’ndeki, konuyla ilgili 1943 yılına ait dosyalar başlıca veri kaynağımız olmuştur.

Anahtar Kelimeler: Türkiye, Doğu Beyazıt, Asayiş, Aşiret, Kürt

\section{ABSTRACT}

The file titled 'Ağrı' which is obtained from the Archive of General Directorate of Security contains important informations about the Sakanlı tribe and the public order of Doğu Beyazit. This research is a two-part study investigating the public order and tribe events at Dogu Beyazit in 1943. In the first part: it is dealed with the political attitude of the Sheikh Abdulkadir, the Chief of the Sakanlı Tribe, who participated in the last phase of Ağrı Rebellion and was protected by Russia and Iran. In the second part of the study, which is about public order, Dogu Beyazit comes to the fore. Because of its geographical location, theft, border violation and inter-tribal struggle are intensely seen here. Therefore, acording to the report, there is no ethnic political attempt after the Ağr1 Rebellion. In this study, the relevant files dated 1943 in the Archives of the General Directorate of Security, became our main data source.

Keywords: Turkey, Dogu Beyazit, Public Order, Tribe, Kurd 


\section{Extended Abstract}

After the Sheikh Sait Rebellion in the Early Republican Period, the biggest rebellion in the Eastern Anatolia Region was the Ağrı Rebellion that lasted for four years between 1926 and1930. The Ağrı Rebellion broke out at a time when the Great Depression has occupied the country's agenda. While the rulers tried to reduce the impact of the economic contraction, they also tried to suppress this uprising, which was attended by different Kurdish tribes in the east.

While the Ağr Rebellion was underway, the government decided to exile some Kurdish tribal leaders, who have the potential to interfere with the military measures, to the western parts of the country. One of them is Sheikh Abdulkadir, the Chief of the Sakanlı Tribe. Although there were people of Sakanlı in the rebellion area, Sheikh Abdulkadir preferred to be passive and did not actually participate in the rebellion initially. Only after he was exiled to Bergama for the second time in 1928 that he decided to take part at the last stage of the uprising.

Participating in the last link of the Ağr Rebellion, Sheikh Abdulkadir, the Chief of the Sakanlı tribe, fled to Iran after the failure of the rebellion. Undoubtedly the biggest factors that facilitated his escape was the fact that Jalal tribe had branches in both Turkey and Iran. Abdulkadir, who used the title of sheikh, dominated other Kurdish tribal groups with his leadership qualities. The Sakanlı chief stayed in Iran for 16 years and cooperated with foreign states, primarily the Russians, vis-a-vis Turkey. Although he also had some contacts with the Iranian state, he was mostly protected by the Russians, as the latter reinforced the tribe with weapons, ammo and money. Indeed, the Russian government wanted to use the Kurdish tribes in the case of a German invasion of the Caucasus during the Second World War or in Turkey's entry into the war on the side of the Axis Powers.

Sheikh Abdulkadir, who took refuge in Iran after the rebellion, continued his contacts within Turkey. He continued his constant communication with either the tribal members or the Iranians he held with money. On the other hand, the Turkish Government followed the Sakanlı tribe and chieftain through their spies. The information and rumours compiled during this period were first evaluated locally and then sent to the capital. In particular, Ağrı and Kars Governorships have made great efforts in this regard.

When the Russians investigated this claim and learned that it was not true, the relations with the Sakanlı became more strained. Sheikh Abdulkadir died n 1946, few 
months after he served as the governor, and the relations between Turkey and the rest of the tribe improved thereafter.

In addition to the public order report, it is possible to find information in various individual sources about the Sakanlı Tribe Chief Sheikh Abdulkadir and his family who took refuge in Iran after the Ağrı Rebellion. The Sakanlı chief did not take part in the first phase of the uprising. Because the government forced him to live in Izmir twice at different times. Being sent into exile was not easy for a tribal leader to easily accept, since the exile shook Sheikh Abdulkadir's authority and brought him under state control. The head of the people of Sakanl1, who drew the first and rejected the second, entered the game at the last link of the attempt. Undoubtedly, explaining the rebellion to the exile only by exile would distort the truth. The process is teeming with Kurdish nationalism and dreams of establishing an independent state. As a result, Sheikh Abdulkadir escaped to Iran, where he would remain until death when he failed. $\mathrm{He}$ intensified relations with the Russians and Iranians during his period as a fugitive.

The main purpose of this study is to reveal the contacts of the Sakanlı Tribe Chief Sheikh Abdulkadir in Iran and reveal the state of security in Ağr1 in 1943. It seeks to examine which states have come into contact with Sakanl, who fled to Iran after the Ağr1 Rebellion, hat crimes are the public order events focused on, whether there was information about the Ağr1 Rebellion and Sakanlı in the public order report dated 1943. This research solely focuses on 1943, Because, in the screening in the Archive of the General Directorate of Security (EGM), the first public order report sent by the Ağr1 Police Department to the Police Department is from this year. No similar reports from previous years could be located. The report is based on East Beyazit. In this context: The causes, development, suppression and results of the Ağr1 Rebellion are not the subject of the research. However, in the context of the subject will be mentioned from place to place. The review first included the Sakanlı tribe, followed by an emphasis public security. 


\section{Giriş}

1926-1930 yılları arasındaki Ağrı İsyanı, Doğu Anadolu Bölgesi’ni dört yıl boyunca kaosa sürüklemiştir. Cumhuriyet'in ilk y1llarında dönemin yöneticilerinin en önemli gündemi, Şeyh Sait İsyanı'ndan sonra bu isyanı bastırmak olmuştur. Ayaklanmanın ortaya çıkışında, Şeyh Sait İsyanı sonrası İhsan Nuri, Berazi Aşiret Reisi Mustafa Bey, Liceli Mustafa Ağa ve arkadaşlarının kurmuş olduğu Hoybun Cemiyeti'nin zararlı çalışmaları ve bunlar neticesinde bir Kürt devleti kurmak istemelerinin önemli etkisi vardır. İsyanın büyümesinde Celali Aşireti Reisi İbrahim Hesiki Paşa’nın Ağrı Valisi olarak atanması da etkili olmuştur. III. Ordu'nun almış olduğu tedbirler sayesinde I. Ağrı İsyanı başarısız olmuş ve asilerin elebaşları İran'a kaçmak zorunda kalmıştır. İkinci isyan ise 14 Eylül 1927 tarihinde Celali Aşireti Reisi İbrahim Hesiki Paşa’nın İran sınırını geçip Ağrı’ya gelmesiyle başlamıştır. İsyancılara Soğanlı, Kızılbaşoğlu, Cilkanlı, Bilhanlı gibi aşiretler de katılmışlardır. Lakin Şark Ordusu'nun sıkı takibi, asileri sıkıntıya düşürmüş ve bir süre sonra da başarısız olmuşlardır ${ }^{1}$.

Kalkışmadan neredeyse çeyrek asır geçmesine rağmen, etkileri Ağrı'da derinden hissedilmiştir. Zira bölgede sınır ihlalleri, kaçakçılık ve devletle problem yaşayan aşiretlerin varlığı, asayişi ve güvenliği bozacak ihlallere kapı aralamıştır. Zaten bu sıkıntılar, öteden beri bir aşiret ritüeline ve geleneksel bir kalıba dönüşmüştür. Nitekim ihlaller 1943 'te de aralıksız devam etmiştir. Asayişsizlik her yıl rapor haline getirilerek üst makamlar bilgilendirilmiştir. Raporda asayiş bilgileri, halkın siyasi temayülleri, ekonomik durumu gibi bir takım detaylı bilgiler mevcuttur.

Asayiş raporuna ilaveten 1943 yılına ait müstakil belgelerde, Ağrı İsyanı sonrası İran'a sığınan Sakanlı Aşireti Reisi Şeyh Abdülkadir ve ailesiyle ilgili bilgileri de bulmak mümkündür. Sakanlı Reisi, ayaklanmanın ilk evresinde rol almamıştır. Çünkü hükûmet, onu farklı zamanlarda iki defa İzmir'de ikamete mücbir etmiştir. Sürgüne gönderilmek, bir aşiret ağasının kolay kolay kabulleneceği bir nakil değildir. Zira sürgün, Şeyh Abdülkadir'in otoritesinin sarsılması ve elinin kolunun bağlanması demektir. İlkini sineye çeken, ikincisini reddeden Sakanlıların Reisi, kalkışmanın son halkasında sürece dâhil olmuştur. Şüphesiz isyana iştiraki sadece sürgünle açıklamak gerçeği çarpitmak olur. Süreç, Kürt milliyetçiliği ve müstakil bir devlet kurma hayalleriyle iç içedir. Neticede Şeyh Abdülkadir, başarısız olunca ölünceye değin kalacağı İran'a firar etmiştir. Kaçaklık yıllarında Ruslar ve İranlılarla münasebetleri yoğunlaştırmıştır.

1 Ahmet İlyas, A ̌ga, Aşiret Siyaset, Ankara, Kadim Yayınları, 2016, s. 109-112. 
Bu çalışmanın temel amacı, Sakanlı Aşireti Reisi Şeyh Abdülkadir'in İran'daki irtibatları ile Doğu Beyazıt'ın 1943 yılına ait asayiş panoramasını ortaya koymaktır. Yine “Ağrı İsyanı sonrası İran’a kaçan Sakanlılarla hangi devletlerin temasa geçtiği”, "asayiş olaylarının hangi suçlar üzerinde yoğunlaştığı", "1943 tarihli asayiş raporunda Ağr1 İsyanı ve Sakanlılarla ilgili bilgilerin olup olmadı̆̆ı” gibi sorulara da cevap verilmiştir. Araştırmanın kronolojik akışı 1943 yılından ibarettir. Çünkü Emniyet Genel Müdürlüğü (EGM) Arşivi'ndeki taramaya göre, Ağrı Emniyet Müdürlüğü’nce Emniyet Umum Müdürlüğü'ne gönderilen Doğu Beyazıt eksenli ilk asayiş raporu 1943 yılına aittir. Daha önceki yıllara ait bir asayiş icmaline tesadüf edilememiştir. Bu çerçevede; Ağrı İsyanı'nın sebepleri, gelişimi, bastırılması ve sonuçları araştırmanın konusu değildir. Lakin konu bağlamında yer yer değinilmiştir. İncelemede ilk önce Sakanlı Aşireti’ne akabinde asayiş icmaline yer verilmiştir. Çalışmayı hazırlarken EGM Arşivi ile bazı ikincil kaynaklar da kullanılmıştır. Bu bağlamda bilgilerinden istifade ettiğim Emniyet Genel Müdürlügü Arşiv ve Dökümantasyon Dairesi eski Başkanı Eyüp Şahin'e müteşekkirim.

\section{Sakanlı Aşireti ve Lideri Şeyh Abdülkadir}

1929 Dünya Ekonomik Buhranı'nın dünyayı ve Türkiye’yi etkilediği bir döneme rast gelen Ağrı İsyan1 ${ }^{2}$, uzun süre ülke gündemini meşgul etmiştir. Yöneticiler, bir yandan ekonomik daralmanın etkisini azaltmaya gayret ederken bir yandan da doğuda fark1ı Kürt aşiretlerinin iştirak ettiği ayaklanmayı bastırmaya çalışmışlardır. Mevsim şartları, fizikî yapı, dış destekli silah ile para takviyesi ve İran Hükûmeti’nin kayıtsız tutumu, Türk Ordusu'nu oldukça zorlamıştır. Dolayısıyla isyan bir türlü bastırılamamış ve zamana yayılmıştır. Hatta asiler, Ağrı Cumhuriyeti’ni bile ilan etmişlerdir. Dört yıllık çabadan sonra Türk Hükûmeti, ayaklanmayı bastırmıştır. Lakin etkileri uzun yıllar Türkiye'de ve İran'da hissedilmiştir.

2 Ağrı İsyanı hakkında ayrıntılı bilgi için bkz. Kemal Kirişçi-Gareth M. Winrow, Kürt Sorunu Kökeni ve Gelişimi, İstanbul, Tarih Vakfi Yurt Yayınları, 2000, s.106-107; Martin Van Bruinessen, A ğa, Şeyh, Devlet, İstanbul, İletişim Yayınları, 2003; İhsan Nuri Paşa, Ağrı Dă̆ İsyanı, İstanbul, Med Yayıncılık, 1992; Bilal Şimşir, İngiliz Belgeleriyle Türkiye'de “Kürt Sorunu” (1924-1938) Şeyh Sait, Ağrl ve Dersim Ayaklanmalarl, Ankara, Dışişleri Bakanlığı Yayınları, 1975; Genelkurmay Belgelerinde Kürt İsyanları, Kaynak Yayınları, C.I, İstanbul, 1992; Emin Karaca, A Agrr Eteklerinde İsyan, İstanbul, Karakutu Yayınları, 2003; Fahri Uçantürk, 1930 Yılı Ağrı Harekâtına Karaköse'den Bir Bakış, Eskişehir, Hava Okulu Matbaası, 1948; Tekin Erer, İstanbul, Kürtçülük Meselesi, Boğaziçi Yayınları, 1994; Naci Kutlay, 21. Yüzyıla Girerken Kürtler, İstanbul, Peri Yayınları, 2002, s. 309-316; Mehmet Köçer, “Ağrı İsyanı (19261930)", Firat Üniversitesi Sosyal Bilimler Dergisi, C.14, S.2, Elazığ, 2004, s. 379-388; Esra Sarıkoyunlu Değer, “Ağr1 İsyanlarında Yabancı Parmağı 1926-1930”, Süleyman Demirel Üniversitesi Fen-Edebiyat Fakültesi Sosyal Bilimler Dergisi, S.18, Isparta, 2008, s. 113-132; Erdal Aydoğan, "Umûmî Müfettişlik Raporlarında Kürtler ve Asayiş Meselesi (1927-1950)”, Tarihte Türkler ve Kürtler Sempozyumu, C.4, Ankara, Türk Tarih Kurumu Yayınları, 2014, s. 304-309. 
İsyan devam ederken Hükûmet, askerî tedbirlerin yanı sıra isyana karışma potansiyeli olan bazı Kürt aşiretlerin liderlerini ülkenin batısındaki yerlere sürgün kararı almıştır. Bunlardan biri de Sakanlı Aşireti Reisi Şeyh Abdülkadir'dir. Her ne kadar isyan sahasında ağırlık olarak Sakanlılar bulunsa da Şeyh Abdülkadir, ayaklanmanın üçüncü yılına kadar fiilen isyana katılmamış, pasif kalmayı tercih etmiştir. Ancak 1928'de ikinci kez Bergama’ya sürgün edilince ayaklanmanın son aşamasında yer almıştır. Şeyh Abdülkadir'in İran'daki sürgün yıllarından -1943- evvel Sakanlı Aşireti'nden bahsetmek, konunun daha iyi anlaşılmasına katkı sağlayacaktır.

Osmanlı döneminden 1930'lu yıllara kadar Çaldıran ve Makü³ arasındaki geniş coğrafyada hayatlarını idame ettiren Celâli Aşireti, dokuz alt koldan oluşmaktadır. Bunlar Sakan, Helikan, Bılgıkan, Mısırkanlı, Cenukanlı, Hasan Suranlı, Kızıl Paşuhlu ve Banuki' dir ${ }^{4}$. Aşiret, Türk, İran ve Rus sınırlarında üç ülkenin de topraklarını kullanmıştır. Zira ekonomisi hayvancılığa dayanan aşiret; Büyük Ağrı ve Ala dağlarını yaylak, İran'daki Hacı Hasan köyünü kışlak olarak tercih etmiştir. Aşiretin mutlak hâkimi; Iğdır, Doğu Beyazıt ve Makü üçgenine yerleşen Sakanlılardır. XX. yüzyıldaki aşiret lideri Şeyh Abdülkadir (Kotan $\left.{ }^{5}\right), 1861$ 'de Hacı Hasan köyünde dünyaya gözlerini açmıştır. I. Dünya Savaşı patlak vermeden kısa bir süre önce aşiretin bir kısmı Doğu Beyazıt'ın Musun (Suluçam) nahiyesine yerleşmiştir ${ }^{6}$.

3 Türkiye, Sovyetler Birliği ve İran arasında cereyan eden Makü sıkıntısıyla ilgili ayrıntılı bilgi için bkz. İbrahim Ethem Atnur, “Türk Sovyet İlişkilerinde Makü Problemi 1920-1921,” Yeni Türkiye Kafkaslar Özel Sayısı, C.1, Ankara, Yeni Türkiye Yayınları, 2015, s. 687-697.

4 XIX. yüzyılın sonlarında Celâli Aşireti toplamda 2.380 haneden oluşmaktadır. Bunlardan 1.200'ü Osmanlı, 880'i İran ve 300'ü de Rus sınırları içerisinde yaşamaktadır. İran'daki Sakalarla akrabalıkları vardır. Türkiye'de daha çok Iğdır'da yaşamaktadırlar. Ayrıntılı bilgi için bkz. Yakup Karataş-Eyüp Kul, "XIX. Yüzyılın Sonlarında Bayezid Sancağındaki Aşiretler ve İskân Politikası”, Atatürk Üniversitesi Türkiyat Araştırmaları Dergisi, S.48, Erzurum 2012, s. 346; Ahmet İlyas, Türkiye'de Aşiret Siyaset İlişkisi: Urfa Örneği (1950-2003), Konya, Selçuk Üniversitesi Sosyal Bilimler Enstitüsü Tarih Anabilim Dalı, Basılmamış Doktora Tezi, 2009, s. 43. Ayrıca 1920'li yıllarda İran'daki Kürt aşiretlerinin etnik ve demografik yapısı için bkz. İbrahim Ethem Atnur, "İsmail Ağa Simko’nun Aşireti, Ailesi ve Reisliğinin İlk Yılları”, Tarihte Türkler ve Kürtler Sempozyumu, C.4, Ankara, Türk Tarih Kurumu Yayınları, 2014, s. 261.

5 1934'te soyadı kanunu çıktığında aşiretin lider kadrosu İran'dadır. Mahmut Kotan, aşiretin Türkiye'deki bakiyeleri için "pulluk" manasına gelen ve kendileriyle hiçbir ilgisi olmayan hatta Örtülü köyünde rekabet halinde oldukları Kotan Aşireti'nin isminin soyadı verildiğini ifade etmektedir. 1942'de doğan Mahmut Kotan, Şeyh Abdülkadir'in torunudur. Babası Şeyh Hasan'dır. Ağrı Tur otobüs firmasının işletmecilerindendir, ancak bir süre sonra bu firmadan ayrılarak müstakil Lüks Ağrı Dağı Seyahat firmasını kurmuştur. Bir dönem Doğu Beyazıt Belediye Başkanlığı da yapmıştır. Ayrıntılı bilgi için bkz. Mücahit Özden Hun, Iğdır Sevdası, Ankara, Alter Yayınları, C.2, 2018, s. 196-197. 
Doğu Beyazıt nüfusuna kayıtlı Şeyh Abdülkadir, Emine, Nazire, Hanife ve Rabia isimli dört kadınla evlenmiştir. Bunlardan Rabia ${ }^{7}$ ile evliliği İran'da olmuştur. İlk eşi Emine'den 1319 (1903) doğumlu Resul, ikinci evliliğinden 1333 (1917) doğumlu Mahmut, üçüncü evliliğinden 1334 (1918) doğumlu Hasan ${ }^{8}$, son evliliğinden de Ali isimli dört oğlu dünyaya gelmiştir. Bunlardan Mahmut İran'da gözlerine dünyaya kapatmıştır. Abdullah isminde bir oğlu olduğu iddia edilmiştir ancak Doğu Beyazıt Kaymakamlığı'nın araştırmaları neticesinde bu isimde bir oğlunun olmadığı tespit edilmiştir.

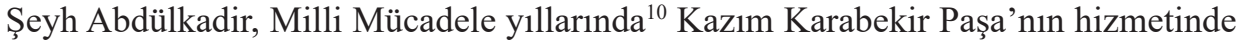
bulunmuş, Iğdır ve Doğu Beyazıt’ta halkı örgütleyerek millî harekete destek vermiştir. Lakin devletle ilişkiler daha sonra ters yüz olmuştur. 16 Mayıs 1926 tarihinde Ağrı İsyanı patlayınca bölgedeki bir takım Kürt aşiret liderleri ve aileleri batıya zorunlu sevke tabi tutulmuşlardır. Nitekim 1926 yılının sonbaharında Şeyh Abdülkadir ve bazı yakınları İzmir Alsancak'a gönderilmişlerdir. Zira isyan bölgesinde ağırlıklı olarak Sakan Aşireti mukimdir. İki yıl sonra Cumhuriyet'in ilanının beşinci yılına atfen çıkartılan afla, aile Doğu Beyazıt'a geri dönmüştür. Ancak Ağrı İsyanı bir türlü yatışmamıştır. Hükûmet ani bir kararla sıkıntılı gördüğü bazı Kürt aşiret liderlerini ikinci kez zorunlu sürgüne gönderme kararı almıştır. Aile bu defa Bergama’ya gönderilmiştir. Lakin ikinci sürgün uzun sürmemiş ve bir fırsatını bulan Şeyh Abdülkadir, memleketine fïrar etmiştir. 1929 yılının ilkbaharında harekete geçen Şeyh Abdülkadir, İran’a geçmeye karar vermiştir. Ancak aşiret mensupları, yol boyunca askerlerle çatışmışlardır. Çatışmada yeğenleri Salih ve Yasin ile aşiret mensuplarından birçoğunu kaybetmişse de İran'a geçmeye muvaffak olmuştur ${ }^{11}$.

25 Eylül 1930 tarihinde Türk Ordusu ayaklanmayı tamamen bastırınca İran Hükûmeti, Kürt aşiret liderlerini göz hapsine alarak Tahran’a götürmüştür. Firar

7 Kendisiyle birlikte İran'a giden ve orada bir süre sonra ölen Kürt aşiret reislerinden Bıro Heseki Telli’nin dul kalan karısı. Şeyh Abdülkadir'in bu evlilikten Ali, Fazile ve Feride isimle üç çocuğu olmuştur. Bunlardan Feride, genç yaşta vefat etmiştir. Torunu Mahmut Kotan, dedesinin beş evlilik yaptığını ifade etmektedir. Lakin resmî kayıtlarda dört evlilik yaptı̆̆ı gözükmektedir. Belki de evliliklerden biri resmî kayıtlara geçmemiş de olabilir. Ayrıntılı bilgi için bkz. Mücahit Özden Hun, I Ĭdır Sevdası..., s. 195.

8 Şah Rıza Pehlevi’nin sınıf arkadaşıdır. Ayrıntılı bilgi için bkz. Mücahit Özden Hun, "Iğdır ve Ağrı Dağı İsyanı 4", (Çevrimiçi), http://hunacademy.com/kotan-sakan-ve-geloylu-kizilbasoglu-asiret-catismalari/, 30 Ocak 2020.

9 EGM Arşivi, Ağrı İsimli 11222-8 Aidiyet Numaralı Dosya, Belge No: 131. Van Valiliği, Seyit Abdullah'ın, Ayan azasından olup Seyit Abdülkadir'in oğlu olduğunu ve Sakanlı Aşireti Reisi Şeyh Abdülkadir'le bir ilgisinin bulunmadığını tespit etmiştir. Ayrıntılı bilgi için bkz. EGM Arşivi, A ğrı İsimli 11222-8 Aidiyet Numaralı Dosya, Belge No: 130 .

10 Mütareke ve Milli Mücadele dönemlerinde ayrılıkçı Kürt hareketleri hakkında ayrıntılı bilgi için bkz. Mehmet Okur, “Milli Mücadele Yıllarında Ayrılıkçı Kürt Girişimlerine Karşı Doğu Vilayetlerinden Meclis-i Mebusan'a ve TBMM'ne Gönderilen Protesto Telgrafları", Atatürk Dergisi, C.4, S.4, Erzurum, 2015, s. 91-105.

11 Mücahit Özden Hun, Ĭgdır Sevdast ..., s. 194. 
konusunda mahirleşen Şeyh Abdülkadir, başkentten de firar ederek Makü’ye kaçmıştır. Sakanlıların yoğun olarak yaşadığ eyalet valisi olarak da Şeyh Abdülkadir atanmıştır. Ancak Mahabad Kürt Cumhuriyeti'nin ömrü uzun olmamıştır. Zaten Şeyh, vali olduktan birkaç ay sonra 85 yaşında hayata gözlerini yummuştur ${ }^{12}$.

Kürt Hükûmeti dağıtılınca İran Hükûmeti, baskısını iyice artırmış dolayısıyla ailenin bir kısmı Türkiye’ye dönerek Iğdır'a yerleşmiştir. Hükûmet, mülteci statüsündeki Sakanlıları uzun müddet burada tutmayarak Kayseri'nin Felahiye ilçesine zorunlu iskâna tabii tutmuştur. Aile iki yıl kadar burada zorunlu kaldıktan sonra Türkiye Cumhuriyeti vatandaşlığı hakkını almış ve eski topraklarına dönmüşlerdir ${ }^{13}$.

\section{2. Şeyh Abdülkadir'in İrtibatları}

SSCB, sıcak denizlere inmek amacıyla Türkiye ve İran'da yaşayan Kürtleri yakından takip etmiştir. Bu amaçla Kürtçülük faaliyetlerine destek vermiştir. "1941 yılında İngiltere'yle yaptığg anlaşma sonucunda İran'ın kuzeyini denetim altına alan SSCB yönetimi, anlaşma şartları gereği kendisine verilen II. Dünya Savaşı sürecinde İran'ın tarafsız kalmasını sağlama amacından uzaklaşarak, ülke içindeki etnik azınlıklar vasıtasıyla burada kendi pozisyonunu güçlendirmeye çalışmıştır. İran'a girdiği ilk günlerden itibaren ülkedeki en büyük etnik azınlıklar olan Azerbaycan Türkleri ve Kürtler arasında ideolojik faaliyetlerde de bulunmayı ihmal etmemiştir"'14. Dolayısıyla Ağrı İsyanı'na katılan ve İran'a sığınan Kürt aşiretleri, SSCB ve İngiltere'nin ilgisini çekmiştir. İran’ın güneyindekilerine İngilizler, kuzeydekilerine Ruslar odaklanmışlardır. Her iki devlet, onlara para ve silah dağıtarak kendi yanlarına çekmeye çalışmıştır ${ }^{15}$. Bazı mülki atamaları aşiret reisleri arasından tercih etmişlerdir. Aşiretlerle irtibatı kesmemişler ve siyasi bir aparat olarak kullanmayı başarmışlardır ${ }^{16}$. Özellikle Ruslar, isyanın son evresine iştirak eden Sakanlı Aşireti ile daha yakından ilgilenerek, onları kimi zaman İran'a kimi zaman da Türkiye'ye karşı kışkırtmıştır.

12 Mücahit Özden Hun, Iğdır Sevdast ..., s. 195.

13 Mücahit Özden Hun, Ĭgdır Sevdası..., s. 195.

14 Marziye Memmedli, "İran Kürtleri (23.12.1946 Tarihli Sovyet Raporuna Göre)", Insan ve Toplum Bilimleri Dergisi, C.9, S.2, İstanbul, 2020, s. 1128

15 Ayrıca Rusların, Şikak Aşireti Reisi Ömer'e dağıtılmak üzere 1.000 yük buğday verdikleri gibi aşiretin atlarına da veteriner hizmeti sundukları iddia edilmiştir. Ancak daha sonra yapılan tahkikatta veterinerlik hizmeti ile buğday meselesinin aslı çıkmamıştır. Ayrıntılı bilgi için bkz. EGM Arşivi, A ̆̆rı İsimli 11222-8 Aidiyet Numaralı Dosya, Belge No: 132-135.

16 Ayrıntılı bilgi için bkz. EGM Arşivi, Ağr İsimli 11222-8 Aidiyet Numaralı Dosya, Belge No: 33-37. 
Genelde Rusların Kürt aşiretlerinden beklentileri şunlardı: "Rusya'ya ihanet edilmemesi, Kürt aşiretlerin Türklerle irtibatta bulunmaması, İran'a karşı birlikte hareket etmeleri, talan ve şekavet yapmamaları". Mutabık kaldıkları hususlardan ayrılmamaları için aşiret temsilcilerine Kur'an-1 Kerim üzerine el bastırılarak yemin ettirilmiştir ${ }^{17}$. İran' da dağınık haldeki Kürt aşiretleri Rusların teşvikiyle Rumiye'de bir toplantı yapmışlar ve Şikak Aşireti Reisi Ömer'i reis seçmişlerdir. Ancak Ömer bunu kabul etmemiş ve Seyit Abdullah'ı önermiştir ${ }^{18}$.

1934’te Sakanlı Aşireti Reisi Şeyh Abdülkadir, İran'da mukim olmasına rağmen, bazen aşiret üyeleri bazen de para karşıllı̆ı kendisine hizmet eden İranlılar aracılığıyla Ağrı ve civarıyla sürekli irtibatta kalmıştır. Parayla tuttuğu adamlardan biri de İranlı Ali Ekber'dir. O, hiçbir kayda girmeden pasaportsuz bir şekilde sık sık Türkiye'yi ziyaret etmektedir. Şüphesiz bu ziyaretlerde bazı kamu görevlileri kendisine yardımcı olmuş, hatta misafir etmişlerdir. Ali Ekber'in beraberinde getirdiği ipekli halı ve kumaş işini oldukça kolaylaştırmıştır. Zira bazen ucuz fiyata elden çıkartmakta bazen de hediye etmektedir. Tüccar kılığıyla 27 Temmuz 1934 tarihinde Serbahan köyünden kiraladığı bir atla, Tüccar Tahir Abdi'den Şeyh Abdülkadir'in alacağını tahsil etmek için Beyazıt'a gitmiştir. Dolayısıyla sık sık temaslarda bulunması kamu görevlilerini kuşkulandırmış ve bir dahaki ziyaretinde gözaltı yapılması kararlaştırılmışıır' ${ }^{19}$. Şeyh Abdülkadir'in Türk-İran sınırını çok sık kullanan elemanlarından bir diğeri de Abdurrezzak'tır ${ }^{20}$. Lakin onun faaliyetleriyle ilgili bir malumat elde edilememiştir.

EGM Arşivi'nde Şeyh Abdülkadir ile ilgili belgelerde yaklaşık sekiz yıllık bir boşluk bulunmaktadır. Belgeler 1942'den itibaren yoğunlaşmaya başlamıştır. Bu yıla ait ilk belge 19 Temmuz 1942 tarihindedir. Belgeden Sakanlı Aşireti Reisi Şeyh Abdülkadir'in, ekseriyeti Kızılbaşoğulları tayfasından olan 300 hanelik bir Kürt nüfusla İran'ın Kaleyni köyüne geldiği anlaşılmaktadır ${ }^{21}$. Fakat Sakanlı Aşireti burada da rahat durmamış ve yağmacıllğa devam etmiştir. Nitekim 14 Ağustos 1942 tarihinde aşiret reisi, adamlarılya Hoy ve Rızaiye'ye ${ }^{22}$ giderek İranlılardan külliyetli miktarda koyun gasp etmişlerdir. Şeyh, akrabaları Helikanlı Aşireti Reisi Halit oğlu Ömer'den de takviye almıştır23.

17 EGM Arşivi, Ağri İsimli 11222-8 Aidiyet Numaralı Dosya, Belge No: 96.

18 Türk Hükûmeti tarafından Güney İran'da Kürt aşiretlerinin faaliyetleri yakından takip edilmiş ve başkentte sürekli bilgi akışı sağlanmıştır. Ayrıntılı bilgi için bkz. EGM Arşivi, A ̆grı İsimli 11222-8 Aidiyet Numaralı Dosya, Belge No: 116-117.

19 EGM Arşivi, Ăgrı İsimli 11222-8 Aidiyet Numaralı Dosya, Belge No: 98-99.

20 EGM Arşivi, Ağrı İsimli 11222-8 Aidiyet Numaralı Dosya, Belge No: 97.

21 EGM Arşivi, A $\breve{g r l}$ Ísimli 11222-8 Aidiyet Numaralı Dosya, Belge No: 45-50.

22 Urumiye/Rumiye.

23 EGM Arşivi, A ̆grı İsimli 11222-8 Aidiyet Numaralı Dosya, Belge No: 42. 
Dolayısıyla Celâli Aşireti’nin mensubu Sakanlı ve Helikanlılar İran'da yağmaya devam etmişlerdir ${ }^{24}$.

Şeyh Abdülkadir ve adamlarının sürekli problem çıkartmaları üzerine Ruslar, 18 Ağustos 1942 tarihinden sonra Sakanlıları Kaleyni köyü civarındaki kuru gölden tahliye ederek Murat Dağları civarındaki Aydize ve Albulak köylerine yerleştirmeye karar vermişlerdir. Aynı karar Helikanlı Aşireti için de tatbik edilecektir ${ }^{25}$. Zira akraba olan her iki aşiret, civar İran köylerini yağmalamakta, buğday toplamakta ve öşür talep etmektedir. Dolayısıyla bu yağma hareketi sırasında sık sık İran jandarmasıyla çatışmalar çıkmaktadır. Hatta jandarmayla çatıştıktan sonra Sakanlılar ve Helikanlılar, İran'ın Danalı köyünü muhasara etmişlerdir. Köy halkından buğday istemişler reddedilince köyün değirmenini zapt etmişlerdir. Olaya müdahale eden İran jandarması, Şeyh Abdülkadir'in adamlarından bazılarını tutuklamıştır. Bunlar arasında sivil kıyafetli Rus askerleri olduğu da görülmüştür. Tutuklananlardan bazıları jandarmanın elinden kaçarak Kürt şakilere sığınmışlardır. Hatta Şeyh Abdülkadir'in oğlu İsmail, kıyafetini değiştirerek canını zor kurtarmıştır ${ }^{26}$.

Kürt şakilerden bıkan İran Hükûmeti, Mors Dağ1 civarında geniş bir temizlik harekâtına başlamıştır. Kürt aşiret liderleriyle görüşen İranlı bir subay, onları itaate davet etmiş; aksi takdirde, öldürüleceklerini belirtmiştir. Teklifi kabul etmeyen Kürt aşiretler, silahı tercih etmişlerdir. Yaşanan çatışmalardan sonra Sakanlılar, Rusların himayesinde bölgeyi terk etmişlerdir ${ }^{27}$.

Yağma hareketleri ile son çatışmada İran jandarmasının ağır kayıp vermesi, İran Kürtleri ile Farsları ${ }^{28}$ karşı karşıya getirmiş ve gerginlik iyice artmıştır ${ }^{29}$. 1942 yılının sonbaharında Sakanlılar, İran’ın “Halun, Morse Dă̆larındaki Albulak, Aşă̆ışadil, Yukarı̧̧adil, Dafo, Dise, Sagaklı, Gülsait ve Bahçekaya Köylerinde” bulunuyorlardı. Yaklaşık 400 hane oldukları tahmin edilen aşiretin yanında 150 tüfek ile 5 ağır makinalı tüfek bulunmaktadır. Ancak İran Hükûmeti; Sakan, Kızılbaş, Halikanlı, Belikanlı,

24 Türk İstihbaratı, Şeyh Abdülkadir'i ve aşiret mensuplarını İran'da rahat bırakmamış ve sürekli izlemiştir. Nitekim Sakanlıların, 15 Ağustos 1942 tarihinde İran'da Sarıçimendağı Yaylası'na geleceği istihbaratını almıştır. Ayrıntılı bilgi için bkz. EGM Arşivi, Ağrı İsimli 11222-8 Aidiyet Numaralı Dosya, Belge No: 41.

25 EGM Arşivi, Ağrı İsimli 11222-8 Aidiyet Numaralı Dosya, Belge No: 40.

26 Nüfus kütüğünü incelediğimizde, Şeyh Abdülkadir'in İsmail isminde bir oğlunun olmadığını görmekteyiz. Her nasılsa belgede aşiret üyelerinden biri olan İsmail, oğlu olarak kayda geçmiştir. Ayrıntılı bilgi için bkz. EGM Arşivi, Ağrı İsimli 11222-8 Aidiyet Numaral Dosya, Belge No: 20-28.

27 EGM Arşivi, A ̈grı İsimli 11222-8 Aidiyet Numaralı Dosya, Belge No: 12-28.

28 Belgelerde her ne kadar Farslılar ifadesi geçse de bölgede ağırlıklı olarak Azerbaycan Türkleri yaşamaktadır.

29 EGM Arşivi, A ğrı İsimli 11222-8 Aidiyet Numaralı Dosya, Belge No: 14-25. 
Mısırkanlı aşiretlerinin Ağrı Dağı'nın doğusuna gitmesine müsaade etmemektedir. Aşiretler de İran köylerini soyduktan sonra kışı Ağrı Dağı'nın doğu eteğindeki Akgöl ve Dambat mıntıkaları ile Aras kenarında geçirmekte ısrar etmişlerdir. Dolayısıyla silahlı çatışma kaçınılmaz olmuştur ${ }^{30}$.

Dâhiliye Vekâleti ve sınır valilikleri İran'daki gelişmeleri yakından takip etmişlerdir. Nitekim aşiretlerin 1942 yılının Ağustos ayından itibaren faaliyetleri hissedilir derece artmıştır. Doğu Beyazıt'ın Tahilki mıntıkasında son zamanlarda yağma olaylarında yoğunluk görülmüştür. Mülki yetkililer ve kolluk birimlerinin sorumluları olağanüstü yoğunluğu Sakanlı Aşireti'ne dayandırmışlardır. Zira onlar, Danalı mıntıkasına geçerken İran'ın Kaçut köyü istikametini kullandıklarından asayiş olayları artmıştır ${ }^{31}$. Ankara'nın sürekli bilgi talep etmesi üzerine Şeyh Abdülkadir ve Ömer, hakkında şahsi dosya açılmasına karar verilmiştir ${ }^{32}$.

Şeyh Abdülkadir'in büyük oğlu Resul'ün İran'a firar etmesi, 1942 yılının son büyük olayıdır. Resul, Ağrı İsyanı sonrası Eleşkirt'in Toprakkale köyünde oturmakta iken ailesini köyde bırakarak, Hanereşk köyünden buğday almak bahanesiyle Eylül 1942'de gizlice İran'ın Danalı mıntıkasında bulunan babasının yanına kaçmıştır. En son Diyadin'in Hacı Halit köyünde görülmüştür. Muhtemelen Tendürek yolunu kullanarak İran'a gittiği ön görülmektedir ${ }^{33}$. Resmî makamlar, firar olayından ancak 15 gün sonra haberdar olmuşlardır. Firar olayı ilk defa Ağrı Hudut Komutanlığı'nca 2 Ekim 1942 tarihinde resmî yazıya dökmüştür. Resul, İran'a geçer geçmez görüşmelerine hız vermiştir. İlk teması, amcazâdesi Şeyh Hasan ve iki Rus subayla buluşmak olmuştur. Akabinde onlarla Harman köyüne, oradan da Kuluşşak köyüne gitmişlerdir. Burada Danalı köyünde öldürülen beş İranlı'nın katili üç Kürt'ü yakalamışlar, sorguya çekmişler ve ellerindeki silahlara el koyarak Danalı'ya dönmüşlerdir. Ağrı Valisi Niyazi Mergen, 28 Aralık 1942 tarihinde Resul'ün Türkiye'ye dönerse gözaltına alınması için tüm tedbirlerin alındığını Dâhiliye Vekâleti'ne iletmiştir ${ }^{34}$. Lakin hiçbir zaman böyle bir gözaltı veya tutuklama eylemi mümkün olmamıştır.

1943 yılındaki belgelerde Şeyh Abdülkadir'in yanı sıra büyük oğlu Resul'ün ailesinin Iğdır'a yerleştirme çabalarıyla ilgili bilgiler ağırlık kazanmaktadır. Sakanlı Aşireti Reisi Şeyh Abdülkadir hakkındaki ilk belge, 21 Ocak 1943 tarihlidir. Bu belgede, Ağrı

30 EGM Arşivi, Ağrl İsimli 11222-8 Aidiyet Numaralı Dosya, Belge No: 24.

31 EGM Arşivi, Ağrı İsimli 11222-8 Aidiyet Numaralı Dosya, Belge No: 4.

32 EGM Arşivi, Ağrı Ísimli 11222-8 Aidiyet Numaralı Dosya, Belge No: 27-31-32.

33 EGM Arşivi, Ağrı İsimli 11222-8 Aidiyet Numaralı Dosya, Belge No: 10.

34 EGM Arşivi, Ağrı İsimli 11222-8 Aidiyet Numaralı Dosya, Belge No: 3. 
Valisi Niyazi Mergen, Şeyh Abdülkadir'in sık sık Rega'ya giderek Rus komutanlarla temas ettiğini; Rusların son görüşmede hafif makinalı tüfek ve cephane verdiklerini; firari Resul'ün şimdilik babasının yanında olmadığını üst makamlara nakletmiştir ${ }^{35}$. Öte yandan Kars Valisi Hüdai Karataban, Iğdır Kaymakamlığı'ndan aldığı bir bilgiyi Dâhiliye Vekâleti'ne iletmiştir. Resmî yazıda şu bilgiler yer almaktadır: "Şeyh Abdülkadir, akrabası Helikanlı Halit oğlu Ömer'in, Türk Hükûmeti'nin casusu olduğunu Ruslara ihbar etmiştir. Bunun üzerine Ruslar, Ömer'i ve Şeyh Abdülkadir'i Revan'a çağırarak olayın iç yüzünü araştırmışlardır. Ömer, Ruslara verdiği ifadesinde, Türk Hükûmetini sevmediğini, Rusların silah verdiği Abdülkadir'in iki hükûmetin arasını bozmaya çalıştığını söylemiştir. Ruslar tutarsız ve ikircikli tavrından dolayı Şeyh Abdülkadir'e verdikleri silahları geri almaya karar vermişlerdir"36.

Ağrı Valisi Niyazi Mergen, 23 Şubat 1943 tarihinde İran ahvâli ve Şeyh Abdülkadir hakkında bir raporu daha Dâhiliye Vekâleti'ne göndermiştir. Raporda "Rusların Sakanlı Aşireti Reisi'ne karşı tutumlarının değiştiği hatta daha önce verilen birtakım silahların geri alındığg, Şeyh Abdülkadir'in mukim olduğu köyün ve evin muhasara altında tutulduğu” belirtilmiştir. Hatta “evin muhasara altında olduğundan haberi olmayan iki Helikanlı Kürt’ten birinin muhafizlar tarafından açılan ateş sonucu öldüğü belirtilmiştir’"37.

Ağrı'daki mülki görevliler dışında bölgedeki gelişmeleri yakından takip eden Kars Valiliği de Mart 1943'te Şeyh Abdülkadir'in evinde yapılan bir toplantının bilgilerini Dâhiliye Vekâleti'ne göndermiştir. Sakanlı Reisi'nin evindeki toplantıdan derlenen bilgiler şöyledir: Rusların İran'daki Kürt ve Ermeni unsurları Türkler ve İranlılar aleyhinde kışkırttıkları, himaye ettikleri görülmektedir. Ancak programlı bir isyan hareketinden ziyade çapulculuk maksadıyla ve mevzi kazanmak amacıyla destek verilmektedir. Mevcudu 18'i geçmeyen iki yağma çetesinin, Türk sınırını geçerek at, eşek ve deve gibi yük ve binek hayvanlarını çaldığ 1 , ancak gerekli tedbirlerin alınmasından sonra Kürtlerin güneydeki dağlık yaylalara çekildiği; Kasım 1942'de 300 kadar Kürt yağmacının Makü’ye saldırdığı ve İran Jandarma Yüzbaşısı Kemal'in idare ettiği müfrezeden 20-30 arası askerin öldürüldüğü ve bunlar arasında iki Rus askerin de bulunduğu ifade edilmiştir. Yazının devamında, Kürt, Ermeni ve bazı İranlıların Tahran’da karışıklıklar çıkarttığı da belirtilmiştir ${ }^{38}$.

35 EGM Arşivi, A ̈̆rı Ísimli 11222-8 Aidiyet Numaralı Dosya, Belge No: 2.

36 EGM Arşivi, Ă̆rı İsimli 11222-8 Aidiyet Numaralı Dosya, Belge No: 141.

37 EGM Arşivi, Ă̆rl Ísimli 11222-8 Aidiyet Numaralı Dosya, Belge No: 139.

38 EGM Arşivi, Ağrı Ísimli 11222-8 Aidiyet Numaralı Dosya, Belge No: 118-119. 
Nisan ayının ilk haftasında soğukların da etkisiyle İran'da müthiş bir kıtlık olmuş ve yiyecek buhranı başlamıştır. Türkiye sınırından üzüm, tütün, yağ ve şeker gibi kaçak emtianın geçişinde artış gözlemlenmiştir Ruslar, her türlü yiyecek ve içeceği toplamaya başlamışlardır. Çaresiz kalan Rus askerler, yiyecek karşılığında askerî malzemelerini satmaya; at ve eşekleri keserek etlerini yemeye başlamışlardır. Dolayısıyla fevkalade bir hayat pahalılığı baş göstermiştir. Şüphesiz Şeyh Abdülkadir ile diğer şaki Kürtlerin bundan etkilenmemesi mümkün değildir. Onlar çözümü yağmaya başlamakla bulmuşlardır ${ }^{39}$.

5 Nisan 1943 tarihinde, Şeyh Abdülkadir ve oğulları hakkında daha tafsilatlı bir bilgiye ulaşmak mümkündür. Şeyhin oğullarından Hasan ve Resul'ün Rone köyünde, yeğeni Şeyh Hasan'ın Danalı köyünde bulunduğu; Şeyh Abdülkadir'in üç aydan beridir Damyat'tan bir yere ayrılmadığı, Rus ve Ermenilerle temasını kâtibi Hamza'nın, Kürtlerle de teması oğulları aracılığıyla yürüttüğü belirtilmiştir. Geçitler İranlılar tarafından kapatılmazsa, karların erimesiyle İran'daki Kürtlerin Iğdır ve Doğu Beyazıt'a gelerek yağma ve soygunculuğa başlayacakları özellikle ifade edilmiştir ${ }^{40}$.

Tedbiri elden bırakmayan Türk İstihbaratı, İran'daki Kürt aşiretlerini izlemeye devam etmiştir. Nitekim baharın gelmesi, havaların 1sınmasıyla karlar eriyince İran'daki Kürt aşiretleri kıpırdanma başlamıştır. Şeyh Abdülkadir'in büyük oğlu Resul, yanındaki 12 adamıyla 7 Mayıs 1943 tarihinde İran'ın Cemalkent köyüne gelerek karların eriyip erimediğini kontrol etmiştir. Zira havaların 1sınmasıyla Erciş veya Patnos üzerinden Türkiye'ye girmeyi planlamaktadır. Yine yerel bilgi kaynakları, Şeyh Abdülkadir'in evinde casusluk işleriyle ilgilendiği tahmin edilen İhsan Nuri adında bir Türk'ün bulunduğu da bildirmişlerdir. Öte yandan Rusların da Türk sınırından içeriye casus gönderebilmek için özellikle fotoğrafsız nüfus cüzdanı temin ettikleri de istihbar kı1ınmıştır ${ }^{41}$.

Temmuz 1943'te, Resul'ün geride kalan aile efradının durumunu ne olacağ kolluk birimlerince tartışılmıştı. Zira yabancı istihbarat servislerinin, aileyle temasa geçip Türkiye aleyhine kullanma ihtimali oldukça yüksekti. Zaten aile ikiye parçalanmıştı. Bir kısmı Türkiye'de bir kısmı İran'da hayatlarına devam ediyorlardı. Uzun süre yazışmalardan sonra Dâhiliye Vekâleti'nin de onayı alınmış ve ailenin Eleşkirt'in Toprakkale köyünden Iğdır'a sevk edilmeleri kararlaştırılmıştır ${ }^{42}$. Nakil işlemi sırasında bir problem

39 EGM Arşivi, A ̆grı İsimli 11222-8 Aidiyet Numaralı Dosya, Belge No: 133.

40 Ağrı Valisi Niyazi Mergen imzasıyla Dâhiliye Vekâleti'ne gönderilen şifreli telgraf. Ayrıntılı bilgi için bkz. EGM Arşivi, Ă̆rı Ísimli 11222-8 Aidiyet Numaralı Dosya, Belge No: 134.

41 EGM Arşivi, Ağrı Ísimli 11222-8 Aidiyet Numaralı Dosya, Belge No: 126.

42 EGM Arşivi, A ̈̆r İsimli 11222-8 Aidiyet Numaralı Dosya, Belge No: 110-111. 
yaşanmaması için aşırı hassasiyet gösterilmiş ve 100 lira da tahsisat ayrılmıştır ${ }^{43}$. Taşınma, kolluk birimlerinin gözetiminde, aile hususiyetlerine dikkat edecek muhafızların eşliğinde olacaktı. Ayriyeten aileden bir erkek de refakat edecekti. Kafile, Eleşkirt’ten Doğu Beyazıt tarikiyle Iğdır'a sevk edilecek ve Iğdır Emniyet Müfettişliği’ne teslim edilecekti ${ }^{44}$.

Sevkiyattan kısa bir süre sonra 26 Ağustos 1943 tarihinde, askerî makamlar zoraki nakle itiraz etmişlerdi. Çünkü Ağrı İsyanı'nın ilk evresinde yer almayan Şeyh Abdülkadir, Alsancak ve Bergama'da zorunlu ikamete tutulmuştu. Bergama'dayken firar eden Sakanlıların reisi, Ağrı İsyanı’nın son evresine katılmış başarısız olduktan sonra İran’a kaçmıştı. Çünkü bir ağanın sürgün edilmesi, gücü ve otoritesinin bitmesi anlamına geliyordu. Ayrıca onursuzluk olarak da telakki ediliyordu. Benzer durum tekerrür edebilirdi. Bu endişeden dolayı aile efradının Iğdır'a yerleştirilmesinden vazgeçilmiş ve 10 Eylül 1943 tarihinde ivedilikle Karaköse’ye yerleştirilmişti ${ }^{45}$.

Şeyh Abdülkadir, ölümünden iki yıl öncesine kadar Doğu Anadolu bölgesindeki asilerle temasını devam ettirmiştir. Zira 1945 ve 1946 yıllarına ait bilgi bulunmamaktadır. Sakanlı Reisi, Muş’tan da destek almıştır. Şeyh Kamil oğlu Şeyh Abdürrahim ile Şubat 1944 'te Ağrı Dağı'nda bir görüşme gerçekleştirdiği ihbarı yapılmıştır. Muş Valiliği, ilk önce ihbara ihtiyatla yaklaşmıştır. Lakin Şeyh Abdülkadir' in belirtilen tarihlerde Ağrı Dağı'na gelip gelmediğini Ağrı Valiliği'ne sormuştur ${ }^{46}$. Belgelerden Valiliğin ne cevap verdiği, görüşmenin meydana gelip gelmediği kıymetlendirilememiştir. 1944 yılına ait bir diğer ve son belge Şeyh Abdülkadir'in oğlu Resul ile ilgilidir. Kars Valisi Ahmet İhsan Aksoy 18 Ağustos 1944 tarihinde Dâhiliye Vekâleti’ne gönderdiği bir telgrafta: “İran'da bulunan Şeyh Abdülkadir'in oğlu Resul'ün pek yakında İran'dan gelerek Karaköse' de bulunan eşini ve çocuklarını kaçıracağını; bu hususta da Iğdır'da Karaağaç mahallesinde mukim Hüseyin Karadă̆'ın yardımcı olacağını bildirdikten sonra gereken tedbirlerin de alındığını" bildirmiştir. Ayrıca Vali Aksoy, civar mülki ve kolluk birimlerinin de bilgilendirildiğini yazısına ilave etmiştir ${ }^{47}$. Şeyh Abdülkadir hakkındaki bilgiler 1944 yılının ortalarından itibaren kesilmektedir. Zaten Sakanlı Reisi, 1946 yılının ilk aylarında kısa bir süre eyalet valiliği yaptıktan sonra son nefesini vermiştir. Onun ölümüyle olayların durulduğunu söylemek mümkündür.

43 EGM Arşivi, A ̆grı İsimli 11222-8 Aidiyet Numaralı Dosya, Belge No: 121.

44 EGM Arşivi, Ağrı İsimli 11222-8 Aidiyet Numaralı Dosya, Belge No: 6-123-124-125.

45 EGM Arşivi, Ă̆rı İsimli 11222-8 Aidiyet Numaralı Dosya, Belge No: 114-115.

46 EGM Arşivi, Ağrı Ísimli 11222-8 Aidiyet Numaralı Dosya, Belge No: 142.

47 EGM Arşivi, Ağrı Ísimli 11222-8 Aidiyet Numaralı Dosya, Belge No: 144. 
Netice itibariyle Ağrı İsyanı'na katılma potansiyelinden dolayı Türk Hükûmeti'nce İzmir'e zorunlu sürgüne tabi tutulan Şeyh Abdülkadir, isyanın ilk aşamasında tarafsız kalmıştır. Lakin isyanın tekrar alevlenmesi sonucu bir kez daha Bergama’ya sürgün edilince oradan kaçmış ve aşiret mensuplarıyla isyana iştirak etmiştir. Ancak, aşiretin lider kadrosu, isyana katılmadıkları ve fakat, İran’a geçerken Türk askeriyle çatıştıkları için asi ilan edildikleri iddiasındadır. Hâlbuki arşiv vesikalarındaki bilgiler bu iddianın muhalifidir. Zira şeyhin ölünceye değin İran'da kalması, İngiltere-Rusya ve İran arasında politik bir enstrüman olarak kullanılması en büyük delildir. Özellikle II. Dünya Savaşı'nın iki müttefiki İngiltere ve Rusya arasında savrulmuştur. Onlardan para, silah ve cephane desteği almıştır. Bu iki büyük devletle çıkar çatışması yaşandıklarında bazen mekânları değiştirilmiş bazen de İran'ın tasarrufuna terk edilmiştir. Dolayısıyla aşiretin lider kadrosu ve mensupları sık sık İran jandarmasıyla çatışmaya girmişlerdir. Şüphesiz bu çatışmalarda köy baskınları, yağma ve hırsızlık da etkili olmuştur. Esasında; Türkiye, İran, SSCB ve İngiltere kıskacında kalan Sakanlılar, bir türlü güven telkin edememişlerdir. Zira Türk Hükûmeti, ailenin Türkiye'deki bakiyeleri ile İran'a sığınanlarını sürekli takip etmiştir. Aşiretin Türk sınırındaki kısmını daha kollayıcı bir tavır geliştirmiştir. Onların sertleşip iyice muhalif olmaması için sürgün gibi bazı uygulamalardan vazgeçmiştir. Şeyh Abdülkadir hayatını kaybettikten sonra Türk Hükûmeti, Sakanlılara daha mülayim davranmıştır. Onların gündelik yaşamları üzerindeki gergin siyasi atmosfer kalkmıştır.

\section{1943 Yılında Ağrı'da Asayiş}

Ağrı'nın 1943 yılına ait asayiş olaylarını II. Dünya Savaşı ile birlikte değerlendirmek gerekir. Her ne kadar Türkiye, II. Dünya Savaşı'na fiilen katılmamışsa da savaşın ekonomik etkilerini derinden hissetmiştir. Zira bir milyona yakın yetişkin erkeğin silahaltına alınması, seferberliğin sürdürülmesi, çift hayvanlarına askerî amaçlarla el konulması tarımsal üretimde ciddi bir gerileme meydana getirmiştir. Zirai ürünler piyasadan kalkmış, karaborsa baş göstermiş, enflasyon yükselmiş ve muhtekirlerin sayısı iyice artmıştır. Ayrıca bütçenin önemli bir bölümü de savunmaya ayrılmıştır. Dolayısıyla böyle bir ortamda asayiş olaylarının artmaması mümkün değildir. Bilhassa sınır şehirlerinde temel ve zaruri ihtiyaçların bazıları kaçakçılık yoluyla temin edilmiştir. Parası olmayanlar, yasal olmayan yollara saparak ayakta kalmaya çalışmışlardır. Neticede savaş yıllarında özelde Ağrı'da genelde Türkiye'de büyük siyasi, askerî, toplumsal ve ekonomik 
bunalımlarından birisi yaşanmıştır. Bu atmosferde 1943 yılına ait Ağrı asayiş raporu ${ }^{48}$ şu bilgileri kapsamaktadır:

\subsection{Asayiş Vaziyeti}

Vilayet dâhilinde emniyet ve asayiş düzenini bozacak, devlet ve hükûmet rejim, otoritesine aykırı bir hal ve hareket görülmemiş, irtica gizli propaganda ve muzır teşekküllerin mevcudiyet ve faaliyetleri hissedilmemiştir. İşlenen adi suçlar daha ziyade yaralanma ve hayvan hırsızlığından ibarettir. Bu suçlarının önüne geçilmesi için icap eden tedbirler alınmıştır. 1943 yılından adi suçlardan işlenen vaka sayısı 450'dir. Geçen yıla nazaran bir miktar artış olmuşsa da bu artış daha ziyade geçim buhranından kaynaklanmaktadir.

Aynı yıl içinde İran hududundan 10 asker, Türkiye'ye iltica etmiş ve bunlar askerî makamlarca kamplara sevk olunmuştur. İran hududundaki tedbirlerin yeterli olmamasından dolayı Ağrı İsyanı sonrası İran'a kaçtıkları ve hududa yakın bazı köylerde bulundukları anlaşılmaktadır. Bu şakilerle İran Kürtleri hududa yakın köylerden hayvan çalıp kaçırmak teşebbüsünde bulunmaktadırlar. Gaye doğrudan doğruya çapulculuktur. 1943 yılında Ağrı İsyanı'ndan sonra İran'a kaçan şakilerle beraber İran eşkıyalarının, hududumuz üzerinde 5 köy basma ve 12 de hayvan hırsızlığı olmak üzere 17 vakaları tespit olunmuştur.

1 Ocak 1943 günü saat 23.30'da Ağrı Dağ1 eteklerindeki Türk hudut köyü olan Tahilke köyü makineli tüfekle mücehhez olan 100 kadar silahlı ve silahsız kuvvetler tarafından basılmış, bir saat kadar köy içinde müsademe yaptıktan sonra köy halkına ait 6.000 koyunla beraber bu çapulcu sürüsü İran'a savuşmuşlardır. Çapulcular, Ağrı Dağı kuzeyini takip ederek Iğdır hududundan İran'a geçtiklerinden ve Türk takip müfrezeleri hadiseyi geç haber almış olduklarından kaçırılan hayvanların bıraktırılması mümkün olamamıştır,

3.1.1. 21-22 Nisan 1943 gecesi Doğu Beyazıt kazasının güneyinde bulunan Menekşe köyü ile Yukarı Sürbahan köyü arasındaki değirmene İran çapulcularından beş silahlı şahıs gelerek değirmende gördükleri üç çuval unu ve 3 baş öküzü alıp hududu

48 Merkez ilçe ile diğer ilçeleri kapsayan rapor, 6 sayfadan ve iki kısımdan mürekkeptir. Birinci kısımda: Asayiş vaziyeti, ikinci kısımda: Halkın ahvâl-i ruhiye ve siyasi temayülleri yer almaktadır. Raporun devamının olup olmadığı müphemdir lakin gidişatta devamının olduğu intibaı uyanmaktadır. 1943 öncesi ve sonrasına ait herhangi bir asayiş raporu olmadığı için mukayese etme firsatı da olmamıştır. Rapor künyesi, sürekli olarak sayfa altı notta tekrar edilmeyecek, bir defa göstermekle yetinilecektir. Raporla ilgili değerlendirme sonuç kısmında yer alacaktır. Ayrıntılı bilgi için bkz. EGM Arşivi, 1943 Tarihli Ağrı Asayiş Raporu, Belge No: 7-12. 
savuşmuşlardır. Vakadan 9 saat sonra haber olunmuş ve yapılan tahkikatta; bunların vaktiyle İran’a kaçmış olan Sürbahan köylü Müşiroğlu Sabri ve Ömer ile Dost Ali köylü Cabbar ve diğerlerinin de İran'dan beraberinde getirdikleri hüviyetleri meçhul 2 şahıs oldukları tespit edilmiş, takibat neticesinde görülen 3 öküz Ağrı eteğindeki inek vadisinde bulunmuştur,

3.1.2. 6 Mayıs 1943 günü saat 12.00 'de Doğu Beyazıt'1n hudut üzerinde bulunan Nazik köy halkına ait bir sığır sürüsü hududa yakın bir yerde otlamakta iken, hududun hemen gerisinde olan 15 silahlı İran çapulcusu grubu, bu sürüyü sürmeye teşebbüs etmiş ise de hudut karakolu tarafindan görülerek yapılan müsademede sürü bıraktırılmış ve yalnız daha evvel hududu geçmiş olan 32 inek ve öküz geri alınamamıştır,

3.1.3. 22 Mayıs 1943 günü saat 22.00'de, Doğu Beyazıt'ın Hazine Gediği hududu karakolunun 89-90 numaralı hudut taşları arasından iki şahsın geçtiği karakol nöbetçisi tarafından görülerek dur emrine itaat etmemeleri üzerine ateş edilmiş ve bunlardan biri öldürülerek diğeri İran topraklarına doğru kaçmaya muvaffak olmuştur. Öldürülen şahsın kimliği tespit edilememiştir,

3.1.4. 25-26 Mayıs 1943 gecesi 18 kadar silahlı İran eşkıyası Doğu Beyazıt'ın Gürbulak hudut köyünün 6 kilometre batısındaki Karga Konmaz köyünü basarak Muhtar Hasan Tan Yeli'ye ait 100 koyunu götürmüşlerdir. Vakadan hemen haberdar olan jandarma birliği, eşkıyayı önleyerek koyunları hudut üzerinde bıraktırmış ve fakat eşkıyalar İran’a kaçmaya muvaffak olmuşlardır,

3.1.5. 7 Haziran 1943 günü saat 18.00'de, Doğu Beyazıt'ın Kızll Kaya hudut karakolu civarında 6 silahlı İran köylüsünün İran'ın Cemalkent köyüne ait hayvan sürüsünün hududdan 200 metre içeri sokulmaları üzerine, bu sürünün geri çevrilmesi için hudut karakolundan gönderilen Türk askerlerine ateş edilmesi üzerine başlayan müsademe sonunda İranlı silahlılarla Cemalkent köyüne çekilerek 40 kuzu ve 9 oğlağı Türk topraklarında bırakmışlardır. Hayvanlar hükûmete teslim edilmiştir,

3.1.6. Ağrı İsyanı sırasında İran'a kaçmış olup, casusluk yapmak maksadıyla Türk topraklarına girdiği Gürbulak hudut bölüğü tarafından görülen ve 8 Haziran 1943 tarihinde yakalanan Nazik köylü Ömer oğlu Tayyar adındaki şahıs, Doğu Beyazıt kazasına sevk edilirken yolda kaçmış ve dur emrine itaat etmediğinden üzerine açılan ateşle ölmüştür,

3.1.7. 23 Haziran 1943 gününde 15 silahlı ve 15 silahsız ki toplam 30 İran eşkıyası, Tendürek Dağı eteğindeki Türk hudut köyü olan Aşağı Zorava köyü civarında otlamakta 
olan 250 koyundan ibaret olan bir sürüyü gasp edip İran'a geçmişlerdir. Vakanın geç haber verilmesinden dolayı yapılan takipten müspet bir netice alınamamıştır,

3.1.8. 26 Haziran 1943 öğleden sonra Doğu Beyazıt'ın Yukarı Zorava köyüne gelen 10 silahlı İran eşkıyasının, köy sürüsünü otlatan çobanı bağlayıp sürüyü sürdükleri haber alınmış ve çıkarılan jandarma müfrezeleri tarafindan yapılan müsademede hayvanlar bıraktırılmıştır. Yapılan müsademede, şakilerden biri sağ olarak yakalanmıştır. Daha sonra Türk müfrezelerini eşkıyanın pususuna düşürdüğü bir sırada önden vurularak öldürülmüştür. Diğer eşkıyalar İran’a kaçmaya muvaffak olmuşlardır,

3.1.9. 2 Temmuz 1943 günü saat 21.30 'da tahminen 40 kadar silahlı İran eşkıyası, huduttan 7 kilometre geride bulunan Karga Konmaz namındaki hudut köyünü basarak köy halkına ait 600 koyun ve keçi ile 37 sığırı, vakanın geç haber verilmesinden dolayı İran'a kaçırmaya muvaffak olmuşlardır,

3.1.10. 4 Temmuz 1943 gecesi saat 24.00 'te, 50 kadar silahlı ve silahsız İran eşkıyas1, Kanlı köyünü basarak köyden aldıkları 600 koyunu çok yakın olan hududu geçirmek suretiyle İran'a götürmüşlerdir. Kanlı Baba hudut karakolu ateş baskısı altına alındığı gibi, geriden de müfrezelerin yetişememesinden eşkıya hayvanatın önlenmesine zaman bırakılmadığı için hayvanat geri alınamamıştır,

3.1.11. 11-12 Temmuz 1943 gecesi, 370 kişiden ibaret dört grup halinde Türk topraklarına girerek Kanlı Baba ve Maşar hudut karakollarına ateş baskısı altına alan İran eşkıyası, Yukarı Sürbahan Yaylası'ndan sürdükleri hayvanatı götürürken; jandarma süvari müfrezesiyle müsademe ettiklerini haber alan diğer jandarma müfrezeleri ve Başkent hudut karakolları, eşkıya ile hudut üzerinde tekrar yaptıkları müsademede, eşkıyanın götürmekte olduğu hayvanatın bir kısmını bıraktırmış ve eşkıyadan 9 ölü Türk topraklarında kalması sağlanmıştır.. Ayrıca 34 yaralı olduğu da sonradan haber alınmıştır. Eşkıya bu vakada 691 koyun, 113 sığır, 11 at ve kısrak götürmüştür,

3.1.12. 19 Temmuz 1943 günü saat 22.00'de 9 silahlı İran eşkıyası Maşar hudut köyümüz civarında otlayan hayvan sürülerini gasp etmiş ise de hudut karakolunun haberdar olarak yaptığı müsademe neticesinde hayvan bıraktırılmış ve çapulcular İran'a kaçmışladır,

3.1.13. 29 Temmuz 1943 günü Ağrı Dağı'nın eteğinde bulunan Örtülü köyü civarında ot getirmeye giden Doğu Beyazıtlı iki şahsın yanında bulunan 5 merkebi 7 silahlı İran eşkıyası gasp etmiş ve bu şahısları da hududa kadar beraber götürmüş olduklarından takip yapmaya zaman kalmadan İran'a geçmişlerdir, 
3.1.14. 30 Kasım 1943 günü İran'dan gelen 100 kadar 6 silahlı ve silahsız eşkıya, hudut civarındaki Zorava ve Kızll Kaya köylerinin otlak yerinden Kızıl Kaya köyüne ait 874 koyun, 57 keçi, 1 ineği; Zorava köyüne ait 1.851 koyun, 369 keçi, 442 sı̆̆ır, 81 at ile kısrak ve 150 merkebi İran’a sürmüş ve Türk müfrezeleri yetişmeden evvel İran topraklarına girmişlerdir. İşin başında eşkıya, Kızıl Kaya hudut karakolunu ateş altına almış ve arkadan gelen Türk müfrezeleriyle eşkıyanın ancak artçıları müsademe etmesine rağmen hayvanatın geçirilmemesi önlenememiştir. Daha sonra eşkıyanın Rus karakollarına hediye olarak bıraktıkları hayvanattan 103 koyun, Ruslar tarafından iade edilmiş ve sahiplerine verilmiştir,

3.1.15. 19 Aralık 1943 günü Doğu Beyazıt mıntıkasının Tendürek Dağı civarındaki Masekent köyüne bağlı Musa köyü civarında jandarma ile müsademe eden ve İran'dan döndükleri anlaşılan Doğu Beyazıt ve Diyadin köyleri halkından 7 kişilik bir kaçakçı kılavuz, Teperizli Mehmet oğlu Ahmet Yardımcı'yı öldürmüş; bunların hepsi yakalanarak adliyeye teslim edilmişlerdir,

3.1.16. 1 Aralık 1943 günü Doğu Beyazıt kazasının Hazine gediği mevkiinden topraklarımıza geçen ve başlarında 2 çocuk çoban bulunan 20 koyun, 10 keçi, 51 kuzu ve 14 oğlaktan ibaret İranlılara ait bir sürü, Türk hudut karakolu tarafından yakalanarak hayvanat mahalli hükûmete teslim edilmiş, çocuklar ise sınır dışına çıkarılmıştır.

Vakaların ortaya çıkmasının temel sebebi Türk-İran sınırında yeterince güvenlik önlemlerinin olmamasıdır. Sınırı korumakla görevli Ağrı Hudut Tümeni hem sayıca hem de teknik olarak yetersiz kalmıştır. Problemi çözmek için adım atan askerî yetkililer, hudut komutanlığı emrindeki jandarma takip müfrezelerini geçiş için önemli bazı köylere dağıtmışlardır. Ayrıca Doğu Beyazıt Jandarma Bölüğü, sık sık devriyeye çıkarak şüphelendikleri köylerde ve noktalarda aramalara başlamışlardır. Yol kontrolleri artırıldığı gibi Iğdır kazası ile Çaldıran nahiyesinde jandarma birlikleri eş güdüm sağlayarak ortak tatbikatlar yapmışlardır. Dolayısıyla tüm bu çabalar müspet neticeler vermiştir.

Rapordan da anlaşılacağı üzere, asayiş olaylarının merkezinde Doğu Beyazıt ve ona bağlı sınır köyleri vardır. Zira İran sınırına en yakın bu yerleşim birimleri, ekonomik sürekliliklerini sağlamak amacıyla kaçakçılığa yönelmişlerdir. Etkileşim halindeki ekonomik süreç, çoğu zaman illegal bir yapıya bürünmüştür. Kaçakçılık dışında, sık sık sınır ihlalleri yapılarak aşiret mensuplarının hırsızlık yaptıkları da aşikârdır. Hareket kabiliyetinden dolayı hırsızlık olaylarında daha çok küçükbaş hayvanlar ön plana çıkmaktadır. Hırsızlık sırasında hayvan sahiplerine ve jandarmaya denk gelen eşkıyalar, silahlı çatışmaya girmekten kaçınmamışlardır. Yakalanmak ve gözaltına alınmak yerine ölmeyi ve 
öldürmeyi tercih etmişlerdir. Zaten rapor incelediğinde görülür ki; neredeyse hiç yakalama olmamış, hırsızlar çok sıkıştıklarında kaçırdıklarını bırakarak sınırdan savuşmayı başarmışlardır. Bir casusluk şüphesinden başka istihbarat ve ideolojik bir olay yaşanmamıştır. Daha çok basit, mala karşı işlenmiş kriminal olaylar karşımıza çıkmaktadır.

\subsection{Halkın Ahvâl-i Ruhiye ve Siyasi Temayülleri}

"Halkın Ahvâl-i Ruhiye ve Siyasi Temayülleri” başlığını taşıyan raporun ikinci bölümü gayet kısadır. Ağrı İsyanı'ndan mülhem olsa gerek daha çok Cumhuriyet rejimine ve yönetime sadakat vurgusu yapılmıştır. Hatta bu bağlılık bazen abartılmıştır. Bölgenin devlet imkânları açısından çok geri kalmasına rağmen halkın, faydalı eserlerden dolayı gayet memnun olduğu ve her türlü ihtiyacının karşılandığı raporlanmıştır. Yine irticadan kalın çizgilerle bahsedilmiştir. Öteden beri bölge halkının cahil hoca ve şeyhlerin yanlış bilgilendirmesiyle körü körüne itaate mecbur tutuldukları ve ağaların esaretinde oldukları ifade edilmiştir. Tüm bu problemlerin Cumhuriyet inkılaplarıyla aşıldığı, halkın gaflet uykusundan uyandığı ve yeni rejimden azami derecede istifade edildiği de rapora ilave edilmiştir. Rejime ve hükûmete sadık bölge halkının, yeni kanunları uygulanmasında da hiçbir zorluk çıkartmadıkları da özellikle belirtilmiştir. Siyaseten her şey yolunda mesajı verilmiştir.

\section{Sonuç}

Araştırmamızda kullandığımız rapor, yazışma tekniği açısından bazı arızaları taşımaktadır. Çünkü hangi kolluk birimince hazırlandığı, hangi makama yazıldığı ve kim tarafından imzalandığı belli değildir. Daha çok Ağrı Emniyet Müdürlüğü’nden, Emniyet Umum Müdürlüğ̈̈’ne yazılmış gibi gözükmektedir. Her şeye rağmen rapor, 1943 yılı Doğu Beyazıt'ına dair asayiş olaylarını kapsaması bakımından gayet kıymetlidir. Bu yılda Doğu Beyazıt'ta isyan, irticai faaliyet gibi kamu düzenini bozacak büyük bir olay yaşanmamıştır. Daha çok büyük ve küçükbaş hayvan kaçakçılı̆̆ının yaşandığı asayiş olayları ön plandadır. Raporda da ifade edildiği üzere 5 köy basılmış ve 12 tanede adli olay meydana gelmiştir. Ayrıca 450 civarında yaralama ve hırsızlık olayından bahsedilmekte ancak detay verilmemektedir. Yekûn bakımından bir önceki yıla göre artış söz konusudur. Lakin kaçakçılıkta tek taraflı bir ihlal mevcuttur. Zira İran tarafindan gelen eşkıya taifesi, Türk sınırını geçerek hayvan hırsızlığı yapmışlardır. Hatta bazen büyük bir sürüyü kaçıracak kadar işi abartmışlardır. Öte yandan Türkiye sınırından İran'a yönelik benzer adli olaylar rapora yansımamıştır. Dolayısıyla hırsızlık olayının tek taraflı olduğu asla düşünülemez. Mukayese ve doğru bilgi edinmek için aynı yılın İran kaynaklarının da incelenmesi gerekmektedir. 
Sınır boyunda olmalarından dolayı, eşkıyalıktan en fazla Doğu Beyazıt ile Ağrı Dağı eteğindeki köyler etkilenmiştir. Sınırdaki jandarma bölüklerinin, bu kadar geniş ve engebeli bir coğrafyayı kontrol etmeleri mümkün değildir. Eşkıyalarla etkin mücadele edebilmek amacıyla bazı bölükler güvenilir köylere serpiştirilmiştir. Iğdır ve Çaldıran'da görevli jandarmalarla iş birliğine gidilmiştir. Alınan tedbirlerin ne kadar etkili olduğunu anlamak için bir sonraki yılın asayiş raporunun görmek gerekir. Ancak böyle bir imkân şu ana kadar mümkün olmamıştır. Her şeye rağmen rapor, Doğu Beyazıt ve İran toponomisi ile aşiret adları hakkında değerli bilgiler vermektedir. Yine soyadı kanununun yürürlükte olduğu bir zamanda, bazı isimlerin hala raporda babalarının ismiyle yan yana kullanıldığını görmekteyiz. İran'dan mülhem sınır tecavüzlerinde ve eşkıyalık olaylarında isimler tespit edilemediğinden sadece sayıları vermekle yetinilmiştir.

Raporun ikinci kısmını oluşturan "Halkın Ahvâl-i Ruhiye ve Siyasi Temayülleri" başlıklı bölüm, dört maddeden oluşmaktadır. Bunlara göz attığımızda daha çok genel geçer ifadeler yer almıştır. Rapor, II. Dünya Savaşı yıllarında Ağrı halkının devletten minnettar olduğu, rejime sadık bulunduğu ifadeleriyle şirin göstermek çabasını yansıtmaktadır. Hâlbuki resmî bir rapordan halkın gerçek memnuniyetini ölçmek oldukça güçtür. Özellikle savaş yıllarının su yüzüne çıkarttığı ekonomik sıkıntının yaşandığı bir dönemde "halkın tüm ihtiyaçları devlet tarafından karşılanıyor" ifadesine kuşkuyla yaklaşmak gerekir. Eğitim imkânlarının artmasıyla halkın, şeyhlerin ve cahil hocaların tasallutundan kurtulduğu ve yasaların tatbikinde hiçbir müşkülatla karşılaşılmadığı da özellikle belirtilmiştir.

Raporda Sakanlı Aşireti ve onun lideri Şeyh Abdülkadir'e ait herhangi bir bilgi bulunmamaktadır. Hâlbuki aşiret, 1943 yılında sınır ötesinde gayet faaldir. Ancak aşiretle ilgili arşivlerdeki malumatlar daha çok istihbarat düzeyinde kalmıştır. Sadece büyük oğul Resul, havaların 1sınmasıyla güzergâhındaki karları kontrol etmiştir ancak Türkiye tarafına geçip geçmediğini müphemdir. Zira bu davranış oldukça risklidir. Çünkü hakkında gözaltı kararı vardır. Raporun sadece 7. maddesinde Ağrı İsyanı ile ilgili bir bilgi mevcuttur. Daha önce isyana iştirak eden akabinde İran'a kaçan ve casus olduğu bilinen Nazik köylü Ömer oğlu Tayyar, 1943 yılında sınırdan geçerken yakayı ele vermiştir. Doğu Beyazıt'a sevk edilirken kaçmaya teşebbüs edince jandarma tarafindan vurularak öldürülmüştür.

Ağrı İsyanı'nın son halkasına katılan Sakanlı Aşireti Reisi Şeyh Abdülkadir, başarısız olduktan sonra İran'a firar etmiştir. Şüphesiz firari kolaylaştıran en büyük etmen Celâli Aşireti'nin hem Türkiye'de hem de İran'da alt kollarının yerleşik olmasıdır. Zaten 
şeyh unvanını kullanan Abdülkadir, liderlik vasıflarıyla diğer Kürt aşiret grupları arasında öne çıkmıştır. İsyandan sonra yaklaşık 16 yıl İran'da kalan Sakanlı Reisi, Türkiye aleyhinde başta Ruslar olmak üzere yabancı devletlerle iş tutmuş, onlar arasında savrulmuştur. İran'la birtakım görüşmelerde bulunmuşsa da daha çok Ruslardan himaye görmüştür. Zira Ruslar, silah, cephane ve parayla aşireti takviye etmişlerdir. Nitekim Rus Hükûmeti, II. Dünya Savaşı'nda Almanların olası bir Kafkasya hareketi sırasında Kürt aşiretleri elinde tutmayı arzuladığı gibi Türkiye'nin Mihver Devletler safinda savaşa girmesi halinde bir alternatif olarak da görmüştür. Gerek Ruslar gerek İranlılar, dünya tarihinin en büyük savaşı sırasında tüm ilgilerini başta Sakanlılar olmak üzere Kürt aşiretlere çevirecek durumda değildirler. Zaten Ruslar, bir süre sonra Şeyh Abdülkadir'den yüz çevirerek ve daha önce dağıttıkları silahları talep etmişlerdir. Ayrıca aşiret üyelerinin sürekli yağma ve çapul hareketleri İran Hükûmeti'ni iyice bıktırmış nihayetinde geniş çağlı bir askerî hareket yapmak zorunda kalmıştır. Bu çatışmalar sırasında esir düşen bazı Rus erlerinin varlığı aradaki ilişkiyi somutlaştırmaktadır.

Şeyh Abdülkadir, İran'da mukimse de eski yaşadığı topraklarla irtibatını hiçbir zaman kesmemiştir. Ya aşiret üyeleriyle ya da parayla tuttuğu İranlılarla sürekli iletişimi devam ettirmiştir. Diğer taraftan Türk Hükûmeti casusları vasıtasıyla Sakanlı Aşireti'ni ve reisini takip ettirmiştir. Derlenen bilgiler ve duyumlar ilk önce mahallinde kıymetlendirilerek başkente gönderilmiştir. Özellikle Ağrı ve Kars valilikleri yoğun çaba sarf etmişlerdir. İsyandan yaklaşık 12 yıl sonra Şeyh Abdülkadir'in büyük oğlu Resul, 1942 sonbaharında babasının yanına kaçmıştır. Bunun üzerine mülki ve kolluk birimleri, Resul'ün geride kalan aile efradının Iğdır'a yerleşmesine karar vermiştir. Lakin askerî makamlar, tarihî tecrübeye binaen bunun yanlışlı̆̆ını beyan ederek kısa sürede tashih ettirmişlerdir.

Zaman ilerledikçe, Sakanlıların akrabası Helikanlı Aşireti Reisi Ömer ile Şeyh Abdülkadir arasında anlaşmazlık giderek artmıştır. Hatta Sakanlı Reisi, Helikanlı Reisi'ni Türkiye lehine casusluk yapmakla itham etmiştir. Bu iddiayı araştıran Ruslar, aslının olmadığını öğrenince Sakanlılarla ilişkileri iyice gerilmiştir. Şeyh Abdülkadir'in 1946 yılında birkaç ay eyalet valiliği yaptıktan sonra vefat etmesiyle aşiret bakiyelerinin Türkiye'yle ilişkileri göreceli olarak düzelmiştir. Aşiretten bazıları önce mülteci statüsüyle ülkeye kabul edilip Kayseri’ye yerleştirilmiş, daha sonra Türk vatandaşlı̆̆ı verilerek eski topraklarına dönmelerine müsaade edilmiştir. 
Hakem Değerlendirmesi: Dış bağımsız.

Çıkar Çatışması: Yazar çıkar çatışması bildirmemiştir.

Finansal Destek: Yazar bu çalışma için finansal destek almadığını beyan etmiştir.

Peer-review: Externally peer-reviewed.

Conflict of Interest: The author has no conflict of interest to declare.

Grant Support: The author declared that this study has received no financial support.

\section{KAYNAKÇA}

\section{Arşiv Kaynakları}

\subsection{Emniyet Genel Müdürlüğ̈̈ (EGM) Arşivi ${ }^{49}$}

1943 Tarihli Ă̆rr Asayiş Raporu, Belge No: 7-12.

A ̆grı İsimli 11222-8 Aidiyet Numaralı Dosya, Belge No:1-156.

\section{Araștırma Eserler}

Atnur, İbrahim Ethem: "Türk Sovyet İlişkilerinde Makü Problemi 1920-1921" Yeni Türkiye Kafkaslar Özel Saylsı, C.1, Ankara, 2015, s. 687-697.

Atnur, İbrahim Ethem: “İsmail Ağa Simko'nun Aşireti, Ailesi ve Reisliğinin İlk Y1lları”, Tarihte Türkler ve Kürtler Sempozyumu, C.4, Ankara, Türk Tarih Kurumu Yayınları, 2014, s. 259-280.

Aydoğan, Erdal: "Umûmî Müfettişlik Raporlarında Kürtler ve Asayiş Meselesi (19271950)”, Tarihte Türkler ve Kürtler Sempozyumu, C.4, Ankara, Türk Tarih Kurumu Yayınları, 2014, s. 299-316.

Erer, Tekin: Kürtçülük Meselesi, İstanbul, Boğaziçi Yayınları, 1994.

Genelkurmay Belgelerinde Kürt İsyanları, C.I, İstanbul, Kaynak Yayınları, 1992.

Hun, Mücahit Özden: Ĭgdır Sevdası, C.2, Ankara, Alter Yayınları, 2018.

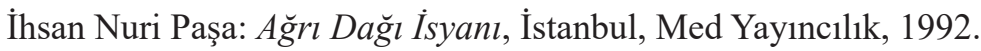

İlyas, Ahmet: A ̆ga, Aşiret Siyaset, Ankara, Kadim Yayınları, 2016.

İlyas, Ahmet: Türkiye'de Aşiret Siyaset İlişkisi: Urfa Örneği (1950-2003), Konya, Selçuk

Üniversitesi Sosyal Bilimler Enstitüsü Tarih Anabilim Dalı, Basılmamış Doktora Tezi, 2009.

Karaca, Emin: A $\breve{g r}$ Eteklerinde İsyan, İstanbul, Karakutu Yayınları, 2003.

49 Faydalanılan arşiv kaynaklarına dair detaylı bilgiler dipnotta verilmiştir. 
Karataş, Yakup-Kul, Eyüp: “XIX. Yüzyılın Sonlarında Bayezid Sancağı’ndaki Aşiretler ve İskân Politikası”, Atatürk Üniversitesi Türkiyat Araştırmaları Dergisi, S.48, Erzurum, 2012, s. 343-364.

Kirişçi, Kemal-Winrow, Gareth M.: Kürt Sorunu Kökeni ve Gelişimi, İstanbul, Tarih Vakfi Yurt Yayınları, 2000.

Köçer, Mehmet: “Ağrı İsyanı (1926-1930)", Firat Üniversitesi Sosyal Bilimler Dergisi, C.14, S.2, Elazı̆̆, 2004, s. 379-388.

Kutlay, Naci: 21. Yüzyıla Girerken Kürtler, İstanbul, Peri Yayınları, 2002.

Memmedli, Marziye: “İran Kürtleri (23.12.1946 Tarihli Sovyet Raporuna Göre)”, Insan ve Toplum Bilimleri Dergisi, C.9, S.2, İstanbul, 2020, s. 1127-1148.

Okur, Mehmet: "Milli Mücadele Yıllarında Ayrılıkçı Kürt Girişimlerine Karşı Doğu Vilayetlerinden Meclis-i Mebusan'a ve TBMM'ne Gönderilen Protesto Telgrafları”, Atatürk Dergisi, C.4, S.4, Erzurum, 2015, s. 91-105.

Sarıkoyunlu Değer, Esra: Ağrı İsyanlarında Yabancı Parmağı 1926-1930”, Süleyman Demirel Üniversitesi Fen-Edebiyat Fakültesi Sosyal Bilimler Dergisi, S.18, Isparta, 2008, s. 113-132.

Şimşir, Bilal: Ingiliz Belgeleriyle Türkiye'de “Kürt Sorunu” (1924-1938) Şeyh Sait, A ̌̆r ve Dersim Ayaklanmaları, Ankara, Dışişleri Bakanlığı Yayınları, 1975.

Uçantürk, Fahri: 1930 Yılı Ağrı Harekâtına Karaköse’den Bir Bakış, Eskişehir, Hava Okulu Matbaası, 1948.

Van Bruinessen, Martin: Ăga, Şeyh, Devlet, İstanbul, İletişim Yayınları, 2003.

\section{Elektronik Kaynaklar}

Hun, Mücahit Özden: "Iğdır ve Ağrı Dağı İsyanı 4", (Çevrimiçi), http://hunacademy. com/kotan-sakan-ve-geloylu-kizilbasoglu-asiret-catismalari/, 30 Ocak 2020. 